\title{
Animal Models for Melioidosis
}

\author{
Kei Amemiya ${ }^{1}$. Joel A. Bozue ${ }^{1} \cdot$ Christopher K. Cote $^{1} \cdot$ David Deshazer $^{1} \cdot$ \\ Carl Soffler $^{1} \cdot$ Susan L. Welkos ${ }^{1}$ • Patricia L. Worsham ${ }^{1}$
}

Published online: 8 November 2017

(C) US Government (outside the USA) 2017

\begin{abstract}
Purpose of Review Development, testing, and evaluation of medical countermeasures for melioidosis are hampered by a lack of well-characterized and standardized animal models. Recent work has both refined existing animal models for this disease and identified new ones.

Recent Findings Head-to-head comparisons of mouse strains with varying susceptibility to the organism and using different routes of infection highlighted and confirmed important similarities and differences between murine models and exposure routes. Diabetic mouse models provided insight into the disease process in humans having this major risk factor. Large animal models, both livestock and non-human primate, have been established. Alternative (non-mammalian) models have been useful in identification of virulence factors and screening of therapeutic candidates. They hold potential for large-scale screening that would not be appropriate or practical for mammalian species.

Summary Recent advances in animal and alternative modeling will enhance our understanding of the organism and the disease process, as well as accelerating the development of medical countermeasures.
\end{abstract}

Keywords Melioidosis $\cdot$ Animal models $\cdot$ In vitro models . Medical countermeasures $\cdot$ Virulence $\cdot$ Burkholderia pseudomallei

This article is part of the Topical Collection on Melioidosis and Tropical Bacteriology

Patricia L. Worsham

Patricia.1.worsham.civ@mail.mil

1 Bacteriology Division, U.S. Army Medical Research Institute of Infectious Diseases (USAMRIID), 1425 Porter St, Fort Detrick, Frederick, MD 21702, USA

\section{Introduction}

Burkholderia pseudomallei is a normal soil and water saprophyte predominately found in Southeast Asia and Northern Australia and the causative agent of the disease melioidosis in these regions and elsewhere, including Africa and the Americas [1, 2]. Melioidosis is considered to be an emerging disease, in part due to improved diagnosis. To a lesser extent, it is also due to migration and transport of infected animals [3-7] and increased immigration from and tourism to endemic regions [8-10], allowing for latent infected hosts to transport the disease to non-endemic regions. Transmission of this disease is thought to be by various routes: oral, respiratory, or breaks in the skin [11-15]. Melioidosis outbreaks have also been reported in a wide variety of animals, including both terrestrial and aquatic mammals, reptiles, birds, and fish in various settings (natural habitat, domestic, and zoological as reviewed in [16-19]). For domestic animals, natural infection is most commonly reported in sheep, goats, and swine [16, 17, 20].

The U.S. Department of Health and Human Services categorizes $B$. pseudomallei as a tier 1 biological select agent. $B$. pseudomallei is thought to pose a threat for use as a biological weapon because (1) hosts are susceptible to infection via aerosol, (2) a long latency period is possible prior to the development of clinical signs, (3) the organism has intrinsic resistance to many antibiotics, and (4) no vaccine is currently available. As such, the biodefense community has taken much interest in developing appropriate animal models for developing medical countermeasures (MCM) for melioidosis. Here, we provide a review of the diverse animal models available for melioidosis that provide a path forward for development of medical countermeasures and future pre-clinical studies. 


\section{Mouse Models}

Mouse models have been extensively used to characterize the pathogenesis of $B$. pseudomallei. Data have illustrated that $\mathrm{BALB} / \mathrm{c}$ mice are more susceptible and may represent an acute model of melioidosis; whereas, C57BL/6 mice are significantly more resistant and may represent a more chronic model of disease. While there is debate about the definition of chronicity in a mouse model, clear differences in susceptibilities are observed in these mice after challenge with B. pseudomallei. Accordingly, work on these two strains constitutes the majority of data available for B. pseudomallei mouse models. Obvious benefits of working with mice include the relatively low cost, ease associated with animal husbandry, and the ability to attain statistical significance with larger animal numbers. One drawback may be the route-associated sensitivities with some of the mouse strains. For example, some strains have a median lethal dose $\left(\mathrm{LD}_{50}\right)$ of less than 1 colony-forming unit (CFU) when delivered as an aerosolized dose. There are also obvious issues associated with the application of data obtained from mouse experiments to human disease $[21,22]$. Table 1 offers a quick reference guide to what we consider important or noteworthy studies designed to characterize the mouse model of melioidosis [24-30, 31•, 32]. Due to space constraints, we have focused mainly on mice exposed to aerosolized bacteria or mice that received intraperitoneal (IP) inoculations. However, other routes have been examined including intravenous (IV), intranasal (IN), and subcutaneous (SC).

Intraperitoneal Exposure The IP route of exposure has been used as an efficient way for characterizing pathogenesis and ranking the virulence of $B$. pseudomalle $i$ clinical isolates. The IP route offers a potential bridge of exposure routes between laboratories for testing as it is easy to perform and there are potentially less variables than when delivering aerosolized bacteria. Welkos et al. demonstrated the IP route of exposure was able to clearly discern differences in virulence associated with a panel of clinical isolates. This report detailed $\mathrm{LD}_{50}$ values calculated for day 21 and day 60 after exposure to the bacteria [30]. Because of the extended endpoint, the importance of observing infected mice for extended periods of time in order to accurately assess the final outcome of the infection was demonstrated. This study has important consequences on the design of vaccine and therapeutic studies, particularly in the choice of bacterial strains and experimental endpoints. Additionally, Welkos et al. provided evidence suggesting an inverse correlation between in vitro and in vivo virulence of $B$. pseuudomallei as determined within the parameters of the macrophage cell model employed. It was shown that strains of $B$. pseudomallei more cytotoxic to in vitro to the J774.A1 tissue culture cells were generally less virulent in the mouse model [30]. While further data are required to substantiate this observation, this inverse correlation may model an important aspect of intracellular B. pseudomallei biology. Other reports have also used the IP model of inoculation (see Table 1), and the cumulative data demonstrate that this model is a valuable tool for $B$. pseudomalle $i$ research. While IP challenge is obviously not a natural route of infection, the resulting disease progression presents with interesting pathology and clinical signs which can be anecdotally compared to human case reports. Some examples described in the literature include pyogranuloma formation in various organs [33,34], primary pneumonia [9] and secondary pneumonia after parenteral inoculation [35], and orbital cellulitis or necrotizing fasciitis [36].

Aerosol Exposure Given that B. pseudomallei is transmitted via exposure to aerosolized bacteria during monsoon seasons in endemic areas and also that $B$. pseudomalle $i$ is a HHS tier 1 agent of concern for biological defense, the aerosol route of exposure is of significant importance [37-39]. Several reports have detailed this route of exposure using both $\mathrm{C} 57 \mathrm{BL} / 6$ and $\mathrm{BALB} / \mathrm{c}$ mice and further characterized the course of disease and importance of the biodefense-driven animal model [25, 26, 29, 31, 32$]$. More recent reports have demonstrated that variation between differentially virulent bacterial strains can be ascertained in an aerosol model [29]. However, whereas the IP model offers a relatively wide range of $\mathrm{LD}_{50}$ values between clinical isolates [30,40], the differences observed in $\mathrm{LD}_{50}$ values when mice are exposed to aerosolized B. pseudomallei are much more subtle. Due to the difficulty in delivering reproducibly small doses of bacteria and the findings revealing a narrower range of virulence differences between clinical isolates, this mouse model is technically challenging and limited to facilities with specialized equipment.

Exposure to aerosolized bacteria results in a primary pneumonia that leads to a highly disseminated disease course in mice (and humans) [9, 29, 31• 32, 34]. The pathologies observed after exposure to aerosolized bacteria have some similarities to those seen after IP inoculation, but the variety and severity of these observations are different than the IP route [31•]. For example, caudal disease progression (e.g., rear end paralysis or tail lesions) can be observed after mice inhale B. pseudomallei but is less commonly observed and may be less severe when contrasted with similar observations in mice receiving the bacteria via an IP injection $[30,31 \bullet]$.

These differences are hypothesized to be due to the initial site of entry and associated with local draining lymph nodes. Even with these important discussion points and caveats, the mouse model offers a highly useful system in which to study bacterial pathogenesis as well as test and evaluate critically needed novel MCMs. 
Table 1 Noteworthy mouse modeling studies for melioidosis

\begin{tabular}{|c|c|c|c|c|}
\hline & $\begin{array}{l}\text { Mouse } \\
\text { strain(s) }\end{array}$ & Route & Bacterial strain(s) & $\begin{array}{l}\text { Key data and experimental } \\
\text { findings presented }\end{array}$ \\
\hline Dannenberg and Scott 1957 [23] & Albino Namru & $\begin{array}{l}\text { IP } \\
\text { Aero }\end{array}$ & $\begin{array}{l}\text { 103-67 (mouse } \\
\text { adapted) }\end{array}$ & $\begin{array}{l}\text { 1. Long time course was examined, up to day } 80 \\
\text { in some cases } \\
\text { 2. Ranges of doses employed (from } 2 \text { to } 100,000 \\
\text { LD }_{50} \text { equivalents) } \\
\text { 3. Examined histopathology and gross pathology } \\
\text { 4. Descriptive immune cell population data presented } \\
\text { 5. Compared chronic disease in mice with humans }\end{array}$ \\
\hline Leakey et al. 1998 [24] & $\begin{array}{l}\mathrm{BALB} / \mathrm{c} \\
\mathrm{C} 57 \mathrm{BL} / 6\end{array}$ & $\begin{array}{l}\text { IV } \\
\text { IP }\end{array}$ & $\begin{array}{l}\text { Clinical isolate from } \\
\text { fatal case in } 1990\end{array}$ & $\begin{array}{l}\text { 1. Provided evidence for differential } \\
\text { model in C57BL/6 mice compared to BALB/c mice } \\
\text { 2. Modeled mainly early disease: most data are } 96 \mathrm{~h} \\
\text { time course with mention of later times } \\
\text { 3. Performed Mendelian analyses with generations } \\
\text { of BALB/c and C57BL/6 mice } \\
\text { 4. Bacterial burden provided for select tissues (blood, } \\
\text { liver, spleen) } \\
\text { 5. Examined growth kinetics in peritoneal exudate } \\
\text { cultures from BALB/c and C57BL/ } 6 \text { mice; } \\
\text { demonstrated that C57BL/6 cells were significantly } \\
\text { more microbicidal than BALB/c cells }\end{array}$ \\
\hline Tan et al. 2008 [25] & $\begin{array}{l}\mathrm{BALB} / \mathrm{c} \\
\mathrm{C} 57 \mathrm{BL} / 6\end{array}$ & $\begin{array}{l}\text { IP } \\
\text { Aero } \\
\text { IN } \\
\text { SC }\end{array}$ & K96243 & $\begin{array}{l}\text { 1. Modeling acute disease: } 6 \text { day time course was } \\
\text { examined with } 3 \text { time points } \\
\text { 2. Cytokine/chemokine expression was reported for } \\
\text { sera and lung samples } \\
\text { 3. Bacterial burden provided for select tissues (nasal } \\
\text { wash, blood, lung, spleen, liver) } \\
\text { 4. Confirmed different susceptibilities of mouse strains } \\
\text { 5. Differential immune responses of the mouse strains: } \\
\text { high levels of pro-inflammatory cytokines were } \\
\text { detrimental and contributed to the immuno-pathogenesis }\end{array}$ \\
\hline Lever et al. 2009 [26] & $\mathrm{BALB} / \mathrm{c}$ & Aero & BRI & $\begin{array}{l}\text { 1. Modeled acute disease: through } 120 \mathrm{~h} \text { with moderate } \\
\text { dose of bacteria ( } 20 \mathrm{LD}_{50} \text { equivalents) } \\
\text { 2. Bacterial burden provided for select tissues } \\
\text { (lung, liver, spleen, blood, kidney, and brain) } \\
\text { 3. Histopathology } \\
\text { 4. Confirmed the sensitivity of the BALB/c mouse to melioidosis }\end{array}$ \\
\hline Srisurat et al. 2010 [27] & $\mathrm{BALB} / \mathrm{c}$ & IP & $\mathrm{A} 2$ & $\begin{array}{l}\text { 1. Exposed mice to high dose ( } 230 \mathrm{CFU} \text { ) or low dose ( } 6 \mathrm{CFU}) \text { to } \\
\text { characterize chronicity } \\
\text { 2. Moderate time course was reported, up to day } 28 \text { in some cases } \\
\text { 3. Bacterial burden provided for select tissues (blood, spleen, } \\
\text { liver, lung) } \\
\text { 4. ELISA data were presented describing resulting antibody } \\
\text { responses }\end{array}$ \\
\hline Conejero et al. 2011 [28] & $\mathrm{C} 57 \mathrm{BL} / 6$ & IN & 576 & $\begin{array}{l}\text { 1. Long time course was examined, up to day } 90 \text { in some cases } \\
\text { 2. Bacterial burden provided for select tissues (blood, liver, spleen) } \\
\text { 3. Cytokine/chemokine expression was reported for sera and lung } \\
\text { 4. Histopathology and gross pathology } \\
\text { 5. Provided evidence that a chronic mouse model of melioidosis } \\
\text { may be similar to that of humans }\end{array}$ \\
\hline Massey et al. 2014 [29] & $\mathrm{BALB} / \mathrm{c}$ & Aero & $\begin{array}{l}\text { K96243; } \\
\text { HBPUB-10303a }\end{array}$ & $\begin{array}{l}\text { 1. Achieved low delivered aerosol dose }(5.4 \text { and } 3.8 \text { cfu) } \\
\text { 2. Data were collected for a short to moderate time frame up to } \\
14 \text { days post exposure } \\
\text { 3. Blood chemistry and hematology parameters were examined } \\
\text { 4. Cytokine/chemokine expression was reported for sera and } \\
\text { lung samples } \\
\text { 5. Bacterial burden provided for select tissues (lung, } \\
\text { liver, spleen) } \\
\text { 6. Examined histopathology } \\
\text { 7. Temperatures and weights were recorded daily } \\
\text { 8. Underscored the importance of standardization of models }\end{array}$ \\
\hline
\end{tabular}


Table 1 (continued)

\begin{tabular}{|c|c|c|c|c|}
\hline & $\begin{array}{l}\text { Mouse } \\
\text { strain(s) }\end{array}$ & Route & Bacterial strain(s) & $\begin{array}{l}\text { Key data and experimental } \\
\text { findings presented }\end{array}$ \\
\hline Welkos et al. 2015 [30] & $\mathrm{BALB} / \mathrm{c}$ & IP & $\begin{array}{l}\text { K96243; 1026b; } \\
\text { 1106a; 406e; } \\
\text { MSHR5858; } \\
\text { MSHR5848; } \\
\text { MSHR5855; } \\
\text { MSHR305; } \\
\text { MSHR668; } \\
\text { HBPUB-1034a; } \\
\text { HBPUB-10303a }\end{array}$ & $\begin{array}{l}\text { 1. Long time course was examined, up to day } 90 \text { in some cases } \\
\text { 2. Bacterial burden provided for select tissues (blood, lung, } \\
\text { spleen and liver) } \\
\text { 3. Cytokine/chemokine expression was reported for sera } \\
\text { and spleen } \\
\text { 4. Characterized immune cell populations with flow cytometry } \\
\text { 5. Histopathology and gross pathology } \\
\text { 6. Established the utility of the IP model for ranking virulence of } \\
\text { clinical isolates based upon } \text { LD }_{50} \\
\text { 7. Presented data suggesting an inverse correlation between } \\
\text { in vitro cytotoxicity and in vivo virulence in the cell model } \\
\text { employed }\end{array}$ \\
\hline Bearss et al. 2017 [31•] & $\begin{array}{l}\text { BALB/c } \\
\text { C57BL/6 }\end{array}$ & $\begin{array}{l}\text { IP } \\
\text { Aero }\end{array}$ & K96243 & $\begin{array}{l}\text { 1. Long time course was examined, up to day } 90 \text { in some cases } \\
\text { 2. Bacterial burden provided for select tissues (blood, lung, spleen) } \\
\text { 3. Cytokine/chemokine expression was reported for sera } \\
\text { and spleen } \\
\text { 4. Characterized immune cell populations with flow cytometry } \\
\text { 5. Histopathology } \\
\text { 6. Delivered purposefully low doses and similar } \text { LD }_{50} \text { equivalent } \\
\text { doses } \\
\text { 7. Comprehensive description of a common lab strain in both } \\
\text { mouse strains using } 2 \text { routes } \\
\text { 8. Documented multi-nucleated giant cell (MNGC) formation } \\
\text { in mice following infection }\end{array}$ \\
\hline
\end{tabular}

$I P$ intraperitoneal, $I V$ intravenous, $I N$ intranasal, $S C$ subcutaneous, Aero aerosol

Diabetic Mouse Models Epidemiological studies have consistently identified diabetes as a major risk factor, with $39-57 \%$ of patients being diabetic or diagnosed with diabetes at presentation [41-43]. Only a limited number of studies have been conducted with either type 1 diabetic (T1D) or T2D diabetic animal models of melioidosis. T2D models are preferable as they represent $90-95 \%$ of all diabetes patients, which also reflects the melioidosis patient population [44]. The earliest models were T1D models induced by streptozotocin treatment in rats or mice [45-50]. In general, the studies reported significant differences between diabetic and normal mice in organ burden, cytokine levels, or gene expression, but none reported significant differences in mortality. Most recently, a model of melioidosis in Akita mice, which have a point mutation in the Ins 2 gene leading to $\beta$ cell apoptosis, has shown a significant difference $(>2.5$ $\log _{10}$ CFU) in the $\mathrm{LD}_{50}$ between diabetic and control animals. It is a T1D model, but characteristics of the T2D phenotype, such as insulin resistance and changes in cardiac structure and function, are present [51].

Type 2 diabetic models have included polygenic/dietinduced and leptin-receptor knockout mouse models [52, 53]. The leptin-receptor knockout $(\mathrm{db} / \mathrm{db})$ is the only model that has shown a statistically significant difference in mortality. However, the $\mathrm{db} / \mathrm{db}$ model is not representative of human T2D in either pathogenesis or severity. The diet-induced diabetic models are believed to be more representative of human diabetes. Relative to control animals, they have shown decreased expression of inflammatory cytokine RNAs, increased inflammatory cell infiltrates, and higher organ burdens early in infection $[52,53]$. All of the above diabetic studies (T1D and T2D) have been conducted in male mice and rats since the females are resistant to develop the diabetic phenotype. This contrasts with virtually all other experimental models of melioidosis, which use only females. The diet-induced diabetic models are also restricted to the C57BL/6 strains (or hybrids). The importance of dietary composition for these models, particularly the fat to sugar/carbohydrate ratio and glycemic index, must be carefully considered. More work is required to generate an appropriate diabetic mouse model of melioidosis.

\section{Hamsters and Guinea Pigs}

The Syrian golden hamster, Mesocricetus auratus, has been utilized since the 1940s as an acute model of experimental melioidosis [23, 54-57]. Male and female hamsters are exquisitely sensitive and uniformly susceptible to infection with $B$. pseudomallei. The $\mathrm{LD}_{50}$ is typically less than $10 \mathrm{CFU}$ and death occurs 2-5 days post-challenge. 
Multiple routes of infection have been utilized, including IP, SC, respiratory, and oral, with little difference in disease progression. Melioidosis in hamsters is an acute fulminating infection with considerable morbidity by $48 \mathrm{~h}$, often with a purulent ocular exudate. Recent studies by Gutierrez and Warawa demonstrated that the body temperature of hamsters infected with B. pseudomallei spikes approximately $24 \mathrm{~h}$ after infection and then drops rapidly immediately prior to death or euthanasia [56]. Systemic infection ultimately results in hamsters that harbor $10^{3}-10^{8} \mathrm{CFU}$ in the blood, liver, spleen, and lungs at disease endpoints.

The intrinsic sensitivity of hamsters to experimental melioidosis has been exploited by researchers to isolate B. pseudomallei from environmental sources [55, 58], characterize non-pathogenic near-neighbor species [54, 59], and identify integral virulence determinants such as the capsular polysaccharide, cluster 1 type VI secretion system (T6SS-1), cluster 3 type III secretion system (T3SS-3), quorum sensing, phospholipase C (PlcN3), and a two-component system sensor kinase (BPSL2025) [60-64]. Tuanyok et al. utilized a whole-genome microarray to compare the RNA expression profile of bacteria growing in infected hamster organs with bacteria grown in vitro and found numerous differentially regulated B. pseudomallei genes important for in vivo metabolism and virulence [62].

Hamsters have also been used as an acute model of infection to confirm the attenuation of $B$. pseudomallei strains subject to removal from the Federal Select Agent Program's select agent list. The strict rules and regulations associated with select agent research apply to B. pseudomallei, and there is a desire by the melioidosis community for strains with attenuated virulence that can be excluded from select agent requirements $[56,65,66]$.

Guinea pigs have been used historically to detect and assess strain virulence of B. pseudomallei [57, 67-69]; however, their recent use as an animal model for melioidosis has been limited. The reported susceptibility of guinea pigs following challenge has varied between being acute (SC and IP) with all of the challenged animal succumbing to infection within a week [70] versus moderately susceptible with a great deal of in variability of survival following IP, SC, ingestion, and inhalational challenge [57]. In a study by DeShazer et al. [71], the $\mathrm{LD}_{50}$ for guinea pigs with strain $1026 \mathrm{~b}$ by the IP route was $2000 \mathrm{CFU}$.

\section{Large Animal Models}

The study of melioidosis in non-rodent, vertebrate models can be broken down into two broad categories: livestock animals and non-human primates (NHP). These models are used much less frequently and have significant limitations relative to their rodent counterparts in terms of biocontainment housing, but have the advantage of being natural host models and, in the case of NHP, having more similarity to humans. Despite the very broad host range of $B$. pseudomallei $[16-18,72]$, studies in wild rodents rarely found evidence of disease or even seropositivity in rats or mice $[73,74]$. In contrast, melioidosis has been well-described in goats, sheep, and other livestock [20,75-89], which parallels disease in humans with the exception that most livestock tends toward chronic presentations of melioidosis with granulomatous lesions [90]. Natural disease in NHPs has been reported as well, but less frequently [3, 4, 7, 91]. Of the species used for experimental models, natural disease (outside of zoological gardens) has only been reported for two rhesus macaques [18]. Both exhibited chronic or reactivated latent disease, with diagnosis 6 months and 10 years after acquisition [3, 91].

Livestock Experimental infection of livestock has been conducted in chickens (IM) [92], horses (SC) [93], cattle (SC) [76, 94], pigs (IV and intratracheal) [95, 96], sheep (SC, IM, IV, supraconjunctival, IN, and oral) [76, 83, 84], and goats (SC, IP, and aerosol) [97-100]. The only species with recent efforts toward the development of livestock models of melioidosis are pigs and goats.

Natural infection in pigs is typically chronic or asymptomatic (discovered only at slaughter) and likely follows oral infection $[20,76,80,86,87,101]$. The pattern of disease after experimental infection generally follows the pattern seen in other species, with a febrile response and multiple organ involvement, but a clear affinity for the lungs and spleen $[95,96]$. Pigs appear to be resistant to acute disease in experimental infection, even with immunosuppression, and additionally appear capable of clearing the infection $[93,95,96]$. Pigs do not appear to be well-suited for the study of naturally occurring human melioidosis or biodefense-related countermeasure assessment.

The goat, as a naturally affected species, has a comparatively large base of the literature describing the presentation and lesions of caprine melioidosis [20, 78-80, 82, 97-99, 102], which compares well with human disease in terms of clinical presentation, epizootiology [16], organ distribution, and histopathology [34, 103]. Acute presentations are possible in goats, but chronic disease is more common and may in some instances self-cure with sterile lesions observed [77, 79, 98, 100]. Experimental infection of goats has been used for developing serodiagnostics (first description of indirect hemagglutination assay), examining the risk of mastitic goats' milk as a source of zoonotic infection, and characterizing disease pathogenesis as a model of human disease [97-100, 104, 105].

Recent aerosol and percutaneous infection studies in goats have provided detailed characterization of the pathology, histopathology, and pulmonary radiographic changes 
associated with caprine melioidosis [99, 100]. Clinical signs of fever and the development of pyogranulomatous lesions in the lungs and spleen were typical of what is seen in humans and experimental models. Bi- to multinucleate giant cells were observed in pulmonary pyogranulomas following percutaneous infection [100], which have been reported from human cases $[34,103,106]$, but they are relatively infrequently reported from animal infection models $[31 \bullet]$.

Livestock models and reports of natural infection provide a valuable insight and comparative study to the field of human melioidosis. The ability of livestock to typically develop chronic disease, and in some cases self-cure, raises interesting ideas of examining different, but successful immune responses to melioidosis. However, the rarity of large animal biocontainment facilities capable of housing livestock coupled with limited immunologic reagents is significant barriers to use of these models.

Non-human Primate Non-human primate (NHP) models are considered the closest approximation to human disease given the close phylogenetic relation and comparable pathologic findings. However, an extremely wide range of susceptibility amongst NHP species exists [4, 57, 107]. Early investigations by Stanton and Fletcher and Miller et al. examined inhalation/ nasal instillation, inoculation, scarification, intraperitoneal, or oral routes of infection, showed cynomolgus macaques (Macaca fascicularis) to be generally resistant to infection $[57,93,108]$, even though outbreaks of melioidosis have been seen in imported cynomolgus macaques [4]. Recent NHP models development efforts have focused primarily on aerosol exposure models in the common marmoset (Callithrix jacchus), rhesus macaque (Macaca mulatta), and African green monkey (Chlorocebus aethiops) [109, 110, 111•, 112, 113]. The focus on aerogenic disease is driven by biodefense imperatives, though the importance of natural inhalational infection $[38,114-116]$ is supported to a similar extent as percutaneous infection [116-119] by epidemiological data.

The marmoset model employs a lower order NHP that is safer and easier to handle in biocontainment conditions compared to old-world monkeys, while still retaining immunologic and physiologic similarities to humans [111•]. Marmosets are extremely susceptible to $B$. pseudomallei with $\mathrm{LD}_{50} \mathrm{~S}$ $<10 \mathrm{CFU}$ and death within $57 \mathrm{~h}$ when exposed to $10^{2} \mathrm{CFU}$ by aerosol [109]. Subcutaneous challenge similarly produced uniformly fatal disease within $85 \mathrm{~h}$ [112]. Disease is severe, acute, and consistent with fever, high levels of bacteremia, and typical lesions in the lung, spleen, and liver. However, lung lesions were notably absent in two thirds of animals infected subcutaneously $[109,112]$. Despite the high susceptibility to $B$. pseudomallei, the marmoset model was able to show differential virulence amongst bacterial strains [111•]. However, factors such as the challenge dose remain more important in determining disease outcome or time to death [111•]. The greatest limitation to the marmoset model is how exquisitely sensitive is to $B$. pseudomallei with very low lethal doses and short times to death. By comparison, primary cutaneous melioidosis in humans is rarely associated with severe disease, whereas even low doses in marmosets produce fatal disease $[112,120]$. This model would represent a very stringent test for therapeutic antimicrobials and is likely too severe for melioidosis vaccine testing.

A comparison of the natural history of inhalation melioidosis (aerosol dose $\sim 3500 \mathrm{CFU}$ ) in rhesus macaques (RM) and African green monkeys (AGM) demonstrated that both species developed an infection that closely resembles that observed in acute human disease, including fever, leukocytosis, neutrophilia, anorexia, and dyspnea. The AGM uniformly developed a rapidly fatal acute disease and were more likely to have systemic involvement. Although 8/10 RM succumbed to acute disease, two survived in the study. One of these had symptoms of chronic pneumonia. Since the AGM was a more consistent model at this dose of B. pseudomallei, it was suggested that the AGM is a more appropriate model for MCM evaluation [110].

\section{Alternative (Non-mammal) Models}

Surrogate hosts have been explored as alternatives for B. pseudomallei challenges to reduce and replace mammals (when possible) for identifying bacterial virulence factors and testing therapeutic candidates. For initial characterization, these alterative models may prove beneficial as they could allow for large-scale screenings which would not be ethically appropriate or practical for mammal species. Furthermore, many of these surrogates have simple growth conditions, short generation times, less ethical and regulatory concerns, and reduced costs and space constraints for performing studies in biocontainment laboratories.

Nematode (Caenorhabditis elegans) The nematode C. elegans is a well-developed surrogate animal model for bacterial pathogenesis studies, and it shares many similarities to the mammalian innate immune system $[121,122]$. The initial study on B. pseudomallei and nematodes demonstrated that this infection was an active process [123]. Further development of this surrogate model has identified additional B. pseudomallei virulence factors [124, 125] and potential therapeutics [126-128].

\section{Madagascar Hissing Cockroach (Gromphadorhina} portentosa) Insects have also proven to be a popular alternative model to mammals as there is a high degree of similarity in the innate immune systems [129]. Recently, the Madagascar hissing cockroach was tested for validity to serve 
as a surrogate model for B. pseudomallei infection. Hemocytes from infected cockroaches appeared to provide an intracellular niche for the bacteria and to also form multinucleated giant cells. The cockroaches were highly susceptible to infection with the $\mathrm{LD}_{50}$ calculated to be $<10 \mathrm{CFU}$. In addition, when comparing $\mathrm{LD}_{50}$ measurements with several B. pseudomallei mutant strains, a clear correlation in virulence was observed between challenged cockroaches and hamsters [130]. A recent study demonstrated the therapeutic potential of the antimalarial drug chloroquine in treating B. pseudomallei-infected cockroaches [131].

Wax Moth (Galleria mellonella) An additional insect which has been examined as an alternative model is the larvae of the wax moth, G. mellonella. The wax moth larvae have been shown to be susceptible to infection with $B$. pseudomallei and able to support growth within the hemocoel [132]. Additional studies have examined B. pseudomallei strains at differing levels of virulence for mice and showed similarities to results obtained with macrophage-like cells and wax moth larvae [133].

Amoeba (Dictyostelium discoideum) B. pseudomallei is an intracellular pathogen that is also able to interact with amoeba. Due to the many similarities between amoeba and macrophages, $D$. discoideum has been explored as a model system using plaque assays to study intracellular survival of B. pseudodmallei [134]. This system may allow greater insight into the mechanisms of virulence of $B$. pseudomallei through studies of intracellular survival and replication.

\section{Animal Models Applied to Pathogenesis and MCM}

Animal models have been used to identify virulence factors (potential targets for antimicrobial and vaccine development), screen prospective vaccines, and therapeutics and evaluate the immune response to B. pseudomallei infection. The advanced development of a promising MCM for human use generally requires testing in a NHP model of disease, especially where controlled studies in humans are not ethically feasible. Only the most promising candidates are typically tested in NHPs due to cost and animal welfare considerations, and only a few melioidosis MCMs have been tested in NHPs [135, 136]. Thus, lower rodent and invertebrate animal models are invaluable resources. Their convenience and similarity in part to the human disease encourages their use in screening and development of novel candidate MCMs.

Numerous studies have been published over the past few years describing the use of $\mathrm{BALB} / \mathrm{c}$ and $\mathrm{C} 57 \mathrm{BL} / 6$ mice to identify novel $B$. pseudomallei virulence determinants and characterize the relative pathogenicity of clinical and laboratory-passaged isolates [137-145, 146•, 147]. Strain competition studies in the mouse model of melioidosis allow the identification and characterization of bacterial genes with mildly attenuated phenotypes [145]. Tn-seq transposon libraries identified 548 genes required for lung colonization and three large gene clusters, capsule, T3SS-3, and T6SS-1, responsible for much of the lung pathogenesis in the intubation-mediated intratracheal (IMIT) murine model of infection [139]. In addition to shedding light on mechanisms of pathogenesis, these types of analyses may aid in the identification of new bacterial targets for the development of MCM.

Recent reviews are available which describe and evaluate candidate melioidosis vaccines and established or novel therapeutics in animal models $[148,149,150 \bullet, 151$, 152-158]. The majority of this work has been done in murine models. Examples of novel therapeutics include new antibiotics, antimicrobial peptides, plant-derived compounds, herbicides, natural toxins/venoms, oligodeoxynucleotides (ODNs), and monoclonal antibodies (MAbs) [127, 159-168]. New regimens for current antibiotics have also been studied. For example, Ruiz et al. reformulated ceftazidime as a dry powder for efficient aerosol delivery to the lungs [169]. In addition to antibacterial treatments, therapeutics that target host pathways involved in responses to infection, or target and stimulate immune cells, such as $\mathrm{T}$ cells, have been characterized in vivo [136, 170-174].

Although some post-exposure therapeutics appeared to prevent B. pseudomallei infection [175], most animals ultimately become colonized and succumb to disease. Thus, vaccine-induced active immunity may be a more promising strategy for preventing infection. Several antigens have been reported to stimulate immunity against infection during the study course [148-154]. Most of these vaccines targeted surface antigens (LPS, capsule, outer membrane proteins, and killed whole cells). Recently, new formulations or platforms for known vaccine targets have provided protection, such as antigen-carrier glycoconjugates, micro- and nanoparticle vaccines, outer membrane vesicles, and killed B. pseudomallei whole cells inactivated by alternate means [135, 176-183]. Alternately, live attenuated B. pseudomallei strains with auxotrophic or virulence factor gene deletions which are significantly attenuating, and recombinant Salmonella and B. thailandensis strains, have been leveraged as live vaccines, with the hope that they will generate more long-term, sterilizing immunity [184-189].

An understanding of the host response to $B$. pseudomallei is critical to MCM development. Although care must be taken in extrapolating immune responses in animal models to human disease, some recent studies have addressed changes in cytokine/chemokine levels in response to the organism [29, 190], the roll of Toll-like receptors (TLRs) in infection [191-202], and the importance of neutrophils in innate immunity [203, 204]. Comparison of mouse strains known 
to differ in susceptibility to B. pseudomallei, such as $\mathrm{BALB} / \mathrm{c}$ and $\mathrm{C} 57 \mathrm{BL} / 6$, suggests that there is an early overt expression of inflammatory cytokines, such as IL- $1 \alpha$, IL$1 \beta$, IL- 6 , and TNF $\alpha$, in the BALB/c mouse compared to that seen in the more resistant C57BL/6 mouse. Similarly, comparing cellular and humoral immune responses in a susceptible NHP host to those of a more resistant one could prove informative. Specific-pathogen-free and genetically modified (knockouts or humanized) mice are available and can be particularly useful for evaluating the immune response and the host-pathogen relationship.

Finally, animal models can be used for other purposes which indirectly support MCM development. These studies (1) spurred the development of select agent exempt stains which facilitate non-containment biosafety laboratory studies on MCMs [184, 205-208], (2) assessed the efficacy of current consensus antibiotic treatment regimens [175, 209-211], (3) probed the role of antibiotic tolerant in vivo variants in treatment failures [212-214], and (4) identified bacterial and host markers which might serve as correlates of protection and immunity [152, 172, 174, 215•, 216, 217]. For instance, a conventional post-exposure treatment regimen failed to eradicate infection in $\mathrm{BALB} / \mathrm{c}$ mice under conditions of immunosuppression or upon extended persistent infection [209]. Also, in a treated mouse model, Cummings et al. characterized transcriptional responses of $B$. pseudomallei specific to ceftazidime exposure to identify markers of treatment efficacy [215•]. Further, long-term and rigorous studies (in mice and then NHPs) to identify countermeasures with the most promise for eradicating infection or producing sterile immunity are required to support the advanced development of human MCM candidates for melioidosis.

\section{Conclusions}

Recently, significant advances have been made in the development of animal models for melioidoisis. These include traditional (rodent), large animal, and alternative models. Head-to-head comparisons of mouse strains with varying susceptibility to the organism, and using different routes of infection, highlighted and confirmed important similarities and differences between murine models and exposure routes. Although diabetic mouse models are relatively early in development, they are providing some understanding of the disease process in the segment of the human population having this major risk factor for melioidosis. Promising large animal models include the goat, a naturally affected species, which compares well with human disease in terms of clinical presentation, organ distribution, and histopathology. However, it requires a biocontainment facility designed for livestock. NHP models, generally considered to be the closest approximation for human disease, vary in susceptibility to B. pseudomallei with the marmoset being exquisitely sensitive, and the AGM being intermediate between the marmoset and the Rhesus macaque. The choice of NHP may vary depending on the goal of the study, for example, testing of therapeutics versus vaccines. Alternative models, such as nematodes, amoebae, and insects, have been primarily useful in the identification of virulence factors and, to a lesser extent, screening of therapeutic candidates. They hold potential for large-scale screening that would not be appropriate or practical for mammalian species. All of these models will contribute to the development of MCM and a better understanding of melioidosis.

\section{Compliance with Ethical Standards}

Conflict of Interest The authors declare that they have no conflict of interest.

Human and Animal Rights and Informed Consent Animal research at the United States Army of Medical Research Institute of Infectious Diseases was conducted and approved under an Institutional Animal Care and Use Committee in compliance with the Animal Welfare Act, PHS Policy, and other Federal statutes and regulations relating to animals and experiments involving animals. The facility where this research was conducted is accredited by the Association for Assessment and Accreditation of Laboratory Animal Care, International and adheres to principles stated in the Guide for the Care and Use of Laboratory Animals, National Research Council, 2011.

Disclaimers Opinions, interpretations, conclusions, and recommendations are those of the authors and are not necessarily endorsed by the U.S. Army.

\section{References}

Papers of particular interest, published recently, have been highlighted as:

- Of importance

•• Of major importance

1. Limmathurotsakul D, Golding N, Dance DA, Messina JP, Pigott DM, Moyes CL, et al. Predicted global distribution of Burkholderia pseudomallei and burden of melioidosis. Nat Microbiol. 2016;1:15008. https://doi.org/10.1038/nmicrobiol. 2015.8.

2. Nachiangmai N, Patamasucon P, Tipayamonthein B, Kongpon A, Nakaviroj S. Pseudomonas pseudomallei in southern Thailand. Southeast Asian J Trop Med Public Health. 1985;16:83-7.

3. Fritz PE, Miller JG, Slayter M, Smith TJ. Naturally occurring melioidosis in a colonized rhesus monkey (Macaca mulatta). Lab Anim. 1986;20:281-5.

4. Dance DA, King C, Aucken H, Knott CD, West PG, Pitt TL. An outbreak of melioidosis in imported primates in Britain. Vet Rec. 1992;130:525-9.

5. Dance DA. Melioidosis: the tip of the iceberg? Clin Microbiol Rev. 1991;4:52-60.

6. White NJ. Melioidosis. Lancet. 2003;361(9370):1715-22. 
7. Ritter JM, Sanchez S, Jones TL, Zaki SR, Drew CP. Neurologic melioidosis in an imported pigtail macaque (Macaca nemestrina). Vet Pathol. 2013;50:1139-44. https://doi.org/10.1177/ 0300985813485249 .

8. Gauthier J, Gerome P, Defez M, Neulat-Ripoll F, Foucher B, Vitry $\mathrm{T}$, et al. Melioidosis in travelers returning from Vietnam to France. Emerg Infect Dis. 2016;22:1671-3. https://doi.org/10.3201/ eid2209.160169.

9. Currie BJ. Melioidosis: an important cause of pneumonia in residents of and travellers returned from endemic regions. Eur Respir J. 2003;22:542-50.

10. Cahn A, Koslowsky B, Nir-Paz R, Temper V, Hiller N, Karlinsky A, et al. Imported melioidosis, Israel, 2008. Emerg Infect Dis. 2009;15:1809-11. https://doi.org/10.3201/eid1511.090038.

11. Currie BJ, Fisher DA, Howard DM, Burrow JN, Selvanayagam S, Snelling PL, et al. The epidemiology of melioidosis in Australia and Papua New Guinea. Acta Trop. 2000;74:121-7.

12. Currie BJ, Mayo M, Anstey NM, Donohoe P, Haase A, Kemp DJ. A cluster of melioidosis cases from an endemic region is clonal and is linked to the water supply using molecular typing of Burkholderia pseudomallei isolates. Am J Trop Med Hyg. 2001;65:177-9.

13. Inglis TJ, Garrow SC, Adams C, Henderson M, Mayo M, Currie BJ. Acute melioidosis outbreak in Western Australia. Epidemiol Infect. 1999;123:437-43.

14. Limmathurotsakul D, Wongsuvan G, Aanensen D, Ngamwilai S, Saiprom N, Rongkard P, et al. Melioidosis caused by Burkholderia pseudomallei in drinking water, Thailand, 2012. Emerg Infect Dis. 2014;20:265-8. https://doi.org/10.3201/eid2002.121891.

15. Limmathurotsakul D, Kanoksil M, Wuthiekanun V, Kitphati R, de Stavola B, Day NP, et al. Activities of daily living associated with acquisition of melioidosis in northeast Thailand: a matched casecontrol study. PLoS Negl Trop Dis. 2013;7:e2072. https://doi.org/ 10.1371/journal.pntd.0002072.

16. Limmathurotsakul D, Thammasart S, Warrasuth N, Thapanagulsak P, Jatapai A, Pengreungrojanachai V, et al. Melioidosis in animals, Thailand, 2006-2010. Emerg Infect Dis. 2012;18:325-7. https://doi.org/10.3201/eid1802.111347.

17. Choy JL, Mayo M, Janmaat A, Currie BJ. Animal melioidosis in Australia. Acta Trop. 2000;74:153-8.

18. Sprague LD, Neubauer H. Melioidosis in animals: a review on epizootiology, diagnosis and clinical presentation. J Vet Med B Infect Dis Vet Public Health. 2004;51:305-20. https://doi.org/10. 1111/j.1439-0450.2004.00797.x.

19. Hicks CL, Kinoshita R, Ladds PW. Pathology of melioidosis in captive marine mammals. Aust Vet J. 2000;78:193-5.

20. Sutmoller P, Kraneveld FC, Van Der Schaaf A. Melioidosis (Pseudomalleus) in sheep, goats, and pigs on Aruba (Netherland Antilles). J Am Vet Med Assoc. 1957;130:415-7.

21. Mestas J, Hughes CC. Of mice and not men: differences between mouse and human immunology. J Immunol. 2004;172:2731-8.

22. Mizgerd JP, Skerrett SJ. Animal models of human pneumonia. Am J Physiol Lung Cell Mol Physiol. 2008;294:L387-98. https://doi.org/10.1152/ajplung.00330.2007.

23. Dannenberg AM Jr, Scott EM. Melioidosis: pathogenesis and immunity in mice and hamsters. I. Studies with virulent strains of Malleomyces pseudomallei. J Exp Med. 1957;107:153-87.

24. Leakey AK, Ulett GC, Hirst RG. BALB/c and C57B1/6 mice infected with virulent Burkholderia pseudomallei provide contrasting animal models for the acute and chronic forms of human melioidosis. Microb Pathog. 1998;24:269-75. https://doi.org/10. 1006/mpat.1997.0179.

25. Tan GY, Liu Y, Sivalingam SP, Sim SH, Wang D, Paucod JC, et al. Burkholderia pseudomallei aerosol infection results in differential inflammatory responses in $\mathrm{BALB} / \mathrm{c}$ and $\mathrm{C} 57 \mathrm{Bl} / 6$ mice. J Med
Microbiol. 2008;57:508-15. https://doi.org/10.1099/jmm.0. 47596-0.

26. Lever MS, Nelson M, Stagg AJ, Beedham RJ, Simpson AJ. Experimental acute respiratory Burkholderia pseudomallei infection in BALB/c mice. Int J Exp Pathol. 2009;90:16-25. https:// doi.org/10.1111/j.1365-2613.2008.00619.x.

27. Srisurat N, Sermswan RW, Tatawasart U, Wongratanacheewin S. Bacterial loads and antibody responses in BALB/c mice infected with low and high doses of Burkholderia pseudomallei. Am J Trop Med Hyg. 2010;82:1102-5. https://doi.org/10.4269/ajtmh. 2010.09-0567.

28. Conejero L, Patel N, de Reynal M, Oberdorf S, Prior J, Felgner PL, et al. Low-dose exposure of C57BL/6 mice to Burkholderia pseudomallei mimics chronic human melioidosis. Am J Pathol. 2011;179:270-80. https://doi.org/10.1016/j.ajpath.2011.03.031.

29. Massey S, Yeager LA, Blumentritt CA, Vijayakumar S, Sbrana E, Peterson JW, et al. Comparative Burkholderia pseudomallei natural history virulence studies using an aerosol murine model of infection. Sci Rep. 2014;4:4305. https://doi.org/10.1038/ srep04305.

30. Welkos SL, Klimko CP, Kern SJ, Bearss JJ, Bozue J, Bernhards $\mathrm{RC}$, et al. Characterization of Burkholderia pseudomallei strains using a murine intraperitoneal infection model and in vitro macrophage assays. PLoS One. 2015;10:e0124667. https://doi.org/10. 1016/j.micpath.2015.07.004.

31. Bearss JJ, Hunter M, Dankmeyer JL, Fritts KA, Klimko CP, Weaver $\mathrm{CH}$, et al. Characterization of pathogenesis of and immune response to Burkholderia pseudomallei K96243 using both inhalational and intraperitoneal infection models in BALB/c and C57BL/6 mice. PloS one. 2017;12:e172627. https://doi.org/10. 1371 /journal.pone.0172627. This study compares two commonly used mouse strains head-to-head using two routes of infection and focusing on histopathology, guiding the choice of mouse models

32. Dannenberg AM Jr, Scott EM. Melioidosis: pathogenesis and immunity in mice and hamsters. I. Studies with virulent strains of Malleomyces pseudomallei. J Exp Med. 1958;107:153-66.

33. Tarlow MJ, Lloyd J. Melioidosis and chronic granulomatous disease. Proc R Soc Med. 1971;64:19-20.

34. Wong KT, Puthucheary SD, Vadivelu J. The histopathology of human melioidosis. Histopathology. 1995;26:51-5.

35. Meumann EM, Cheng AC, Ward L, Currie BJ. Clinical features and epidemiology of melioidosis pneumonia: results from a 21year study and review of the literature. Clin infect dis : off pub Infect Dis Soc Am. 2012;54:362-9. https://doi.org/10.1093/cid/ cir808.

36. Saonanon P, Tirakunwichcha S, Chierakul W. Case report of orbital cellulitis and necrotizing fasciitis from melioidosis. Ophthal Plast Reconstr Surg. 2013;29:81-4. https://doi.org/10.1097/IOP. 0b013e318275b601.

37. Chen PS, Chen YS, Lin HH, Liu PJ, Ni WF, Hsueh PT, et al. Airborne transmission of melioidosis to humans from environmental aerosols contaminated with B. pseudomallei. PLoS negl trop dis. 2015;9:e0003834. https://doi.org/10.1371/journal.pntd. 0003834 .

38. Currie BJ, Jacups SP. Intensity of rainfall and severity of melioidosis. Australia Emerg Infect Dis. 2003;9:1538-42.

39. Liu X, Pang L, Sim SH, Goh KT, Ravikumar S, Win MS, et al. Association of melioidosis incidence with rainfall and humidity, singapore, 2003-2012. Emerg Infect Dis. 2015;21:159-62. https://doi.org/10.3201/eid2101.140042.

40. Challacombe JF, Stubben CJ, Klimko CP, Welkos SL, Kern SJ, Bozue JA, et al. Interrogation of the Burkholderia pseudomallei genome to address differential virulence among isolates. PLoS One. 2014;9:e115951. https://doi.org/10.1371/journal.pone. 0115951. 
41. Hassan MR, Pani SP, Peng NP, Voralu K, Vijayalakshmi N, Mehanderkar R, et al. Incidence, risk factors and clinical epidemiology of melioidosis: a complex socio-ecological emerging infectious disease in the Alor Setar region of Kedah, Malaysia. BMC Infect Dis. 2010;10:302. https://doi.org/10.1186/1471-2334-10302.

42. Currie BJ, Ward L, Cheng AC. The epidemiology and clinical spectrum of melioidosis: 540 cases from the 20 year Darwin prospective study. PLoS Negl Trop Dis. 2010;4:e900. https://doi.org/ 10.1371/journal.pntd.0000900.

43. Limmathurotsakul D, Wongratanacheewin S, Teerawattanasook N, Wongsuvan G, Chaisuksant S, Chetchotisakd P, et al. Increasing incidence of human melioidosis in Northeast Thailand. Am J Trop Med Hyg. 2010;82:1113-7. https://doi.org/ 10.4269/ajtmh.2010.10-0038.

44. Currie B. Pseudomonas pseudomallei-insulin interaction. Infect Immun. 1995;63:3745.

45. Woods DE, Jones AL, Hill PJ. Interaction of insulin with Pseudomonas pseudomallei. Infect Immun. 1993;61:404550.

46. Maniam P, Nurul Aiezzah Z, Mohamed R, Embi N, Hasidah MS. Regulatory role of GSK3 beta in the activation of NF-kappaB and modulation of cytokine levels in Burkholderia pseudomallei-infected PBMC isolated from streptozotocin-induced diabetic animals. Trop Biomed. 2015;32:36-48.

47. Williams NL, Morris JL, Rush C, Govan BL, Ketheesan N. Impact of streptozotocin-induced diabetes on functional responses of dendritic cells and macrophages towards Burkholderia pseudomallei. FEMS Immunol Med Microbiol. 2011;61:218 27. https://doi.org/10.1111/j.1574-695X.2010.00767.x.

48. Chin CY, Monack DM, Nathan S. Delayed activation of host innate immune pathways in streptozotocin-induced diabetic hosts leads to more severe disease during infection with Burkholderia pseudomallei. Immunology. 2012;135:312-32. https://doi.org/10. 1111/j.1365-2567.2011.03544.x.

49. Koh GC, Weehuizen TA, Breitbach K, Krause K, de Jong HK, Kager LM, et al. Glyburide reduces bacterial dissemination in a mouse model of melioidosis. PLoS Negl Trop Dis. 2013;7:e2500. https://doi.org/10.1371/journal.pntd.0002500.

50. Chin CY, Monack DM, Nathan S. Genome wide transcriptome profiling of a murine acute melioidosis model reveals new insights into how Burkholderia pseudomallei overcomes host innate immunity. BMC Genomics. 2010;11:672. https://doi.org/10.1186/ 1471-2164-11-672.

51. Hong EG, Jung DY, Ko HJ, Zhang Z, Ma Z, Jun JY, et al. Nonobese, insulin-deficient Ins2Akita mice develop type 2 diabetes phenotypes including insulin resistance and cardiac remodeling. Am J Physiol Endocrinol Metab. 2007;293:1687-96. https:// doi.org/10.1152/ajpendo.00256.2007.

52. Hodgson KA, Govan BL, Walduck AK, Ketheesan N, Morris JL. Impaired early cytokine responses at the site of infection in a murine model of type 2 diabetes and melioidosis comorbidity. Infect Immun. 2013;81:470-7. https://doi.org/10.1128/IAI. 00930-12.

53. Hodgson KA, Morris JL, Feterl ML, Govan BL, Ketheesan N. Altered macrophage function is associated with severe Burkholderia pseudomallei infection in a murine model of type 2 diabetes. Microbes and infection / Institut Pasteur. 2011;13: 1177-84. https://doi.org/10.1016/j.micinf.2011.07.008.

54. Brett PJ, DeShazer D, Woods DE. Characterization of Burkholderia pseudomallei and Burkholderia pseudomallei-like strains. Epidemiol Infect. 1997;118:137-48.

55. Ellison DW, Baker HJ, Mariappan M. Melioidosis in Malaysia. I. A method for isolation of Pseudomonas pseudomallei from soil and surface water. Am J Trop Med Hyg. 1969;18:694-7.
56. Gutierrez MG, Warawa JM. Attenuation of a select agentexcluded Burkholderia pseudomallei capsule mutant in hamsters. Acta Trop. 2016;157:68-72.

57. Miller WR, Pannell L, Cravitz L, Tanner WA, Rosebury T. Studies on certain biological characteristics of Malleomyces mallei and Malleomyces pseudomallei. II. Virulence and infectivity for animals. J Bacteriol. 1948;55:127-35.

58. Finkelstein RA, Atthasampunna P, Chulasamaya M. Pseudomonas (Burkholderia) pseudomallei in Thailand, 1964 1967: geographic distribution of the organism, attempts to identify cases of active infection, and presence of antibody in representative sera. Am J Trop Med Hyg. 2000;62:232-9.

59. DeShazer D. Virulence of clinical and environmental isolates of Burkholderia oklahomensis and Burkholderia thailandensis in hamsters and mice. FEMS Microbiol Lett. 2007;277:64-9.

60. Burtnick MN, Brett PJ, Harding SV, Ngugi SA, Ribot WJ, Chantratita N, et al. The cluster 1 type VI secretion system is a major virulence determinant in Burkholderia pseudomallei. Infect Immun. 2011;79:1512-25.

61. Reckseidler SL, DeShazer D, Sokol PA, Woods DE. Detection of bacterial virulence genes by subtractive hybridization: identification of capsular polysaccharide of Burkholderia pseudomalle $i$ as a major virulence determinant. Infect Immun. 2001;69:34-44.

62. Tuanyok A, Tom M, Dunbar J, Woods DE. Genome-wide expression analysis of Burkholderia pseudomallei infection in a hamster model of acute melioidosis. Infect Immun. 2006;74:5465-76.

63. Ulrich RL, DeShazer D, Brueggemann EE, Hines HB, Oyston PC, Jeddeloh JA. Role of quorum sensing in the pathogenicity of Burkholderia pseudomallei. J Med Microbiol. 2004;53:1053-64.

64. Warawa J, Woods DE. Type III secretion system cluster 3 is required for maximal virulence of Burkholderia pseudomallei in a hamster infection model. FEMS Microbiol Lett. 2005;242:101-8.

65. Norris MH, Propst KL, Kang Y, Dow SW, Schweizer HP, Hoang TT. The Burkholderia pseudomallei $\Delta$ asd mutant exhibits attenuated intracellular infectivity and imparts protection against acute inhalation melioidosis in mice. Infect Immun. 2011;79:4010-8.

66. Propst KL, Mima T, Choi KH, Dow SW, Schweizer HP. A Burkholderia pseudomallei $\Delta p u r M$ mutant is avirulent in immunocompetent and immunodeficient animals: candidate strain for exclusion from select-agent lists. Infect Immun. 2010;78:313643.

67. M V. Presence probable du bacille de Whitmore dans l'eau de mare au Tonkin. Bull Soc Pathol Exot. 1937;30:10-5.

68. McCormick JB, Weaver RE, Hayes PS, Boyce JM, Feldman RA. Wound infection by an indigenous Pseudomonas pseudomalleilike organism isolated from the soil: case report and epidemiologic study. J Infect Dis. 1977;135:103-7.

69. Chambon L. Isolation of Whitmore's bacillus from external environment. Ann Inst Pasteur (Paris). 1955;89:229-35.

70. Manzeniuk IN, Galina EA, Dorokhin VV, Kalachev I, Borzenkov VN, Svetoch EA. Burkholderia mallei and Burkholderia pseudomallei. Study of immuno- and pathogenesis of glanders and melioidosis. Heterologous vaccines. Antibiot Khimioter. 1999;44:21-6.

71. DeShazer D, Brett PJ, Woods DE. The type II O-antigenic polysaccharide moiety of Burkholderia pseudomallei lipopolysaccharide is required for serum resistance and virulence. Mol Microbiol. 1998;3:1081-100.

72. Kasantikul T, Sommanustweechai A, Polsrila K, Kongkham W, Chaisongkram C, Sanannu S et al. Retrospective study on fatal melioidosis in captive zoo animals in Thailand. Transbound Emerg Dis 2016;63(5):e389-94. https://doi.org/10.1111/tbed. 12315.

73. Strauss JM, Ellison DW, Gan E, Jason S, Marcarelli JL, Rapmund G. Melioidosis in Malaysia. IV. Intensive ecological study of 
Carey Island, Selangor, for Pseudomonas pseudomallei. Med J Malaya. 1969;24:94-100.

74. Harries EJ, Lewis AA, Waring JWB, Dowling EJ. Melioidosis treated with sulphonamides and penicillin. Lancet. 1948;1:363-6.

75. Fatimah I, Ikede BO, Mutalib RA. Granulomatous orchitis and periorchitis caused by Pseudomonas pseudomallei in a goat. Vet Rec. 1984;114:67-8.

76. Laws L, Hall WTK. Melioidosis in animals in north Queensland. 1. Incidence and pathology, with special reference to central nervous system lesions. Queensland J Agric Sci. 1963;20:499-513.

77. Laws L, Hall WTK. Melioidosis in animals in North Queensland IV. Epidemiology. Aust Vet J. 1964;40:309-14. https://doi.org/10. 1111/j.1751-0813.1964.tb04524.x.

78. Lewis FA, Olds RJ. Melioidosis in sheep and a goat in North Queensland. Aust Vet J. 1952;28:145-50. https://doi.org/10. 1111/j.1751-0813.1952.tb05152.x.

79. Olds RJ, Lewis FA. Melioidosis in goats. Aust Vet J. 1954;30: 253-61. https://doi.org/10.1111/j.1751-0813.1954.tb05416.x.

80. Omar AR. Pathology of melioidosis in pigs, goats and a horse. $\mathrm{J}$ Comp Pathol. 1963;73:359-72.

81. Retnasabapathy A. Isolation of Pseudomonas pseudomallei from an aborted goat foetus. Vet Rec. 1966;79:166.

82. Van der Lugt JJ, Henton MM. Melioidosis in a goat. J S Afr Vet Assoc. 1995;66:71-3.

83. Cottew GS. Melioidosis in sheep in Queens land; a description of the causal organism. Aust J Exp Biol Med Sci. 1950;28:677-83.

84. Cottew GS, Sutherland AK, Meehan JF. Melioidosis in sheep in Queensland: description of an outbreak. Aust Vet J. 1952;28:11323. https://doi.org/10.1111/j.1751-0813.1952.tb05138.x.

85. Ketterer PJ, Donald B, Rogers RJ. Bovine melioidosis in SouthEastern Queensland. Aust Vet J. 1975;51:395-8.

86. Ketterer PJ, Webster WR, Shield J, Arthur RJ, Blackall PJ, Thomas AD. Melioidosis in intensive piggeries in south eastern Queensland. Aust Vet J. 1986;63:146-9.

87. Thomas AD, Norton JH, Forbes-Faulkner JC, Woodland G. Melioidosis in an intensive piggery. Aust Vet J. 1981;57:144-5.

88. Ladds PW, Thomas AD, Pott B. Melioidosis with acute meningoencephalomyelitis in a horse. Aust Vet J. 1981;57:36-8.

89. Stanton AT, Fletcher W, Symonds SL. Melioidosis in a horse. J Hyg (Lond). 1927;26:33-5.

90. Brundage WG, Thuss CJ Jr, Walden DC. Four fatal cases of melioidosis in U. S. soldiers in Vietnam. Bacteriologic and pathologic characteristics. Am J Trop Med Hyg. 1968;17:183-91.

91. Kaufmann AF, Alexander AD, Allen MA, Cronin RJ, Dillingham LA, Douglas JD, et al. Melioidosis in imported non-human primates. J Wildl Dis. 1970;6:211-9.

92. Vesselinova A, Najdenski H, Nikolova S, Kussovski V. Experimental melioidosis in hens. Zentralbl Veterinarmed B. 1996;43:371-8.

93. Stanton AT, Fletcher W. Melioidosis: studies from the Institute of Medical Research of Federated Malay States. London: John Bale \& Sons and Danielson Ltd; 1932.

94. Nicolls L. Melioidosis, with special reference to the dissociation of Bacillus whitmori. Br J Exp Pathol. 1930;11:393-9.

95. Najdenski H, Kussovski V, Vesselinova A. Experimental Burkholderia pseudomallei infection of pigs. J Vet Med B Infect Dis Vet Public Health. 2004;51:225-30. https://doi.org/10.1111/j. 1439-0450.2004.00754.x.

96. Thomas AD, Forbes-Faulkner JC, D'Arcy TL, Norton JH, Hoffmann D. Experimental infection of normal and immunosuppressed pigs with Pseudomonas pseudomallei. Aust Vet J. 1990;67:43-6.

97. Narita M, Loganathan P, Hussein A, Jamaluddin A, Joseph PG. Pathological changes in goats experimentally inoculated with Pseudomonas pseudomallei. Natl Inst Anim Health Q (Tokyo). 1982;22:170-9.
98. Thomas AD, Forbes-Faulkner JC, Norton JH, Trueman KF. Clinical and pathological observations on goats experimentally infected with Pseudomonas pseudomallei. Aust Vet J. 1988;65: 43-6.

99. Soffler C, Bosco-Lauth AM, Aboellail TA, Marolf AJ, Bowen RA. Development and characterization of a caprine aerosol infection model of melioidosis. PLoS One. 2012;7:e43207. https://doi. org/10.1371/journal.pone.0043207.

100. Soffler C, Bosco-Lauth AM, Aboellail TA, Marolf AJ, Bowen RA. Pathogenesis of percutaneous infection of goats with Burkholderia pseudomallei: clinical, pathologic, and immunological responses in chronic melioidosis. Int J Exp Pathol. 2014;95: 101-19. https://doi.org/10.1111/iep.12068.

101. Millan JM, Mayo M, Gal D, Janmaat A, Currie BJ. Clinical variation in melioidosis in pigs with clonal infection following possible environmental contamination from bore water. Vet J. 2007;174:200-2. https://doi.org/10.1016/j.tvj1.2006.05.006.

102. Tonpitak W, Sornklien C, Chawanit M, Pavasutthipaisit S, Wuthiekanun V, Hantrakun V, et al. Fatal melioidosis in goats in Bangkok. Thailand Am J Trop Med Hyg. 2014;91:287-90. https://doi.org/10.4269/ajtmh.14-0115.

103. Piggott JA, Hochholzer L. Human melioidosis. A histopathologic study of acute and chronic melioidosis. Arch Pathol. 1970;90: 101-11.

104. Ileri SZ. The indirect haemagglutination test in the diagnosis of melioidosis in goats. Br Vet J. 1965;121:164-70.

105. Thomas AD, Spinks GA, D'Arcy TL, Norton JH, Trueman KF. Evaluation of four serological tests for the diagnosis of caprine melioidosis. Aust Vet J. 1988;65:261-4.

106. Greenawald KA, Nash G, Foley FD. Acute systemic melioidosis. Autopsy findings in four patients. Am J Clin Pathol. 1969;52:188 98.

107. Warawa JM. Evaluation of surrogate animal models of melioidosis. Front Microbiol. 2010;1:141. https://doi.org/10. 3389/fmicb.2010.00141.

108. Stanton AT, Fletcher W. Melioidosis and its relation to glanders. J Hyg (Lond). 1925;23:347-63.

109. Nelson M, Dean RE, Salguero FJ, Taylor C, Pearce PC, Simpson AJ, et al. Development of an acute model of inhalational melioidosis in the common marmoset (Callithrix jacchus). Int $\mathrm{J}$ Exp Pathol. 2011;92:428-35. https://doi.org/10.1111/j.13652613.2011.00791.x.

110. Yeager JJ, Facemire P, Dabisch PA, Robinson CG, Nyakiti D, Beck K, et al. Natural history of inhalation melioidosis in rhesus macaques (Macaca mulatta) and African green monkeys (Chlorocebus aethiops). Infect Immun. 2012;80:3332-40. https://doi.org/10.1128/IAI.00675-12.

111. Nelson M, Nunez A, Ngugi SA, Sinclair A, Atkins TP. Characterization of lesion formation in marmosets following inhalational challenge with different strains of Burkholderia pseudomallei. Int j exp pathol. 2015;96:414-26. https://doi.org/ 10.1111/iep.12161. This paper provides a nice summary of marmoset work to date

112. Nelson M, Salguero FJ, Dean RE, Ngugi SA, Smither SJ, Atkins TP, et al. Comparative experimental subcutaneous glanders and melioidosis in the common marmoset (Callithrix jacchus). Int J Exp Pathol. 2014;95:378-91. https://doi.org/10.1111/iep.12105.

113. Yingst SL, Facemire P, Chuvala L, Norwood D, Wolcott M, Alves DA. Pathological findings and diagnostic implications of a rhesus macaque (Macaca mulatta) model of aerosol-exposure melioidosis (Burkholderia pseudomallei). J Med Microbiol. 2014;63:118-28. https://doi.org/10.1099/jmm.0.059063-0.

114. Cheng AC, Jacups SP, Gal D, Mayo M, Currie BJ. Extreme weather events and environmental contamination are associated with case-clusters of melioidosis in the Northern Territory of 
Australia. Int J Epidemiol. 2006;35:323-9. https://doi.org/10. 1093/ije/dyi271.

115. Chou DW, Chung KM, Chen $\mathrm{CH}$, Cheung BM. Bacteremic melioidosis in southern Taiwan: clinical characteristics and outcome. J Formos Med Assoc. 2007;106:1013-22. https://doi.org/ 10.1016/S0929-6646(08)60077-7.

116. Rammaert B, Beaute J, Borand L, Hem S, Buchy P, Goyet S, et al. Pulmonary melioidosis in Cambodia: a prospective study. BMC Infect Dis. 2011;11:126. https://doi.org/10.1186/1471-2334-11126.

117. Phuong DM, Trung TT, Breitbach K, Tuan NQ, Nubel U, Flunker $\mathrm{G}$, et al. Clinical and microbiological features of melioidosis in northern Vietnam. Trans R Soc Trop Med Hyg. 2008;102(Suppl 1):S30-6. https://doi.org/10.1016/S0035-9203(08)70009-9.

118. Suputtamongkol Y, Hall AJ, Dance DA, Chaowagul W, Rajchanuvong A, Smith MD, et al. The epidemiology of melioidosis in Ubon Ratchatani, northeast Thailand. Int $\mathrm{J}$ Epidemiol. 1994;23:1082-90.

119. Suputtamongkol Y, Chaowagul W, Chetchotisakd P, Lertpatanasuwun N, Intaranongpai S, Ruchutrakool T, et al. Risk factors for melioidosis and bacteremic melioidosis. Clin Infect Dis. 1999;29:408-13. https://doi.org/10.1086/520223.

120. Gibney KB, Cheng AC, Currie BJ. Cutaneous melioidosis in the tropical top end of Australia: a prospective study and review of the literature. Clin infect dis : off pub Infect Dis Soc Am. 2008;47: 603-9. https://doi.org/10.1086/590931.

121. Kim DH, Feinbaum R, Alloing G, Emerson FE, Garsin DA, Inoue $\mathrm{H}$, et al. A conserved p38 MAP kinase pathway in Caenorhabditis elegans innate immunity. Science. 2002;297:623-6. https://doi. org/10.1126/science.1073759.

122. Shivers RP, Pagano DJ, Kooistra T, Richardson CE, Reddy KC, Whitney JK, et al. Phosphorylation of the conserved transcription factor ATF-7 by PMK-1 p38 MAPK regulates innate immunity in Caenorhabditis elegans. PLoS Genet. 2010;6:e1000892. https:// doi.org/10.1371/journal.pgen.1000892.

123. O'Quinn AL, Wiegand EM, Jeddeloh JA. Burkholderia pseudomallei kills the nematode Caenorhabditis elegans using an endotoxin-mediated paralysis. Cell Microbiol. 2001;3:381-93.

124. Wong RR, Kong C, Lee SH, Nathan S. Detection of Burkholderia pseudomallei toxin-mediated inhibition of protein synthesis using a Caenorhabditis elegans ugt-29 biosensor. Sci Rep. 2016;6: 27475. https://doi.org/10.1038/srep27475.

125. Lee SH, Wong RR, Chin CY, Lim TY, Eng SA, Kong C, et al. Burkholderia pseudomallei suppresses Caenorhabditis elegans immunity by specific degradation of a GATA transcription factor. Proc Natl Acad Sci U S A. 2013;110:15067-72. https://doi.org/10. 1073/pnas.1311725110.

126. Biggins JB, Ternei MA, Brady SF. Malleilactone, a polyketide synthase-derived virulence factor encoded by the cryptic secondary metabolome of Burkholderia pseudomallei group pathogens. J Am Chem Soc. 2012;134:13192-5. https://doi.org/10.1021/ ja3052156.

127. Eng SA, Nathan S. Curcumin rescues Caenorhabditis elegans from a Burkholderia pseudomallei infection. Front Microbiol. 2015;6:290. https://doi.org/10.3389/fmicb.2015.00290.

128. Lim MP, Firdaus-Raih M, Nathan S. Nematode peptides with host-directed anti-inflammatory activity rescue Caenorhabditis elegans from a Burkholderia pseudomallei infection. Front Microbiol. 2016;7:1436. https://doi.org/10.3389/fmicb.2016. 01436.

129. Vilmos P, Kurucz E. Insect immunity: evolutionary roots of the mammalian innate immune system. Immunol Lett. 1998;62:59 66.

130. Fisher NA, Ribot WJ, Applefeld W, DeShazer D. The Madagascar hissing cockroach as a novel surrogate host for Burkholderia pseudomallei $B$ mallei and $B$ thailandensis. BMC microbiol. 2012;12:117. https://doi.org/10.1186/1471-2180-12-117.

131. Chua J, Senft JL, Lockett SJ, Brett PJ, Burtnick MN, DeShazer D, et al. $\mathrm{pH}$ alkalinization by chloroquine suppresses pathogenic Burkholderia type 6 secretion system 1 and multinucleated giant cells. Infect Immun. 2017;85:e0586-16. https://doi.org/10.1128/ IAI.00586-16.

132. Schell MA, Lipscomb L, DeShazer D. Comparative genomics and an insect model rapidly identify novel virulence genes of Burkholderia mallei. J Bacteriol. 2008;190:2306-13. https://doi. org/10.1128/JB.01735-07.

133. Wand ME, Muller CM, Titball RW, Michell SL. Macrophage and Galleria mellonella infection models reflect the virulence of naturally occurring isolates of $B$. pseudomallei, $B$. thailandensis and B. oklahomensis. BMC Microbiol. 2011;11:11. https://doi.org/10. 1186/1471-2180-11-11.

134. Hasselbring BM, Patel MK, Schell MA. Dictyostelium discoideum as a model system for identification of Burkholderia pseudomallei virulence factors. Infect Immun. 2011;79:2079-88. https://doi.org/10.1128/IAI.01233-10.

135. Petersen H, Nieves W, Russell-Lodrigue K, Roy CJ, Morici LA. Evaluation of a Burkholderia pseudomallei outer membrane vesicle vaccine in nonhuman primates. Procedia Vaccinol. 2014;8: 38-42. https://doi.org/10.1016/j.provac.2014.07.007.

136. Laws TR, Nelson M, Bonnafous C, Sicard H, Taylor C, Salguero $\mathrm{FJ}$, et al. In vivo manipulation of gamma $9^{+} \mathrm{T}$ cells in the common marmoset (Callithrix Jacchus) with phosphoantigen and effect on the progression of respiratory melioidosis. PLoS One. 2013;8: e74789. https://doi.org/10.1371/journal.pone.0074789.

137. Biggins JB, Kang HS, Ternei MA, DeShazer D, Brady SF. The chemical arsenal of Burkholderia pseudomallei is essential for pathogenicity. J Am Chem Soc. 2014;136:9484-90. https://doi. org/10.1021/ja504617n.

138. Custódio R, McLean CJ, Scott AE, Lowther J, Kennedy A, Clarke DJ, et al. Characterization of secreted sphingosine-1-phosphate lyases required for virulence and intracellular survival of Burkholderia pseudomallei. Mol Microbiol. 2016;102:1004-19. https://oi.org/10.1111/mmi.13531.

139. Gutierrez MG, Yoder-Himes DR, Warawa JM. Comprehensive identification of virulence factors required for respiratory melioidosis using Tn-seq mutagenesis. Front Cell Infect Microbiol. 2015;5:78. https://doi.org/10.3389/fcimb.2015.00078.

140. Lazar Adler NR, Allwood EM, Lucas DD, Harrison P, Watts S, Dimitropoulos A, et al. Perturbation of the two-component signal transduction system, BprRS, results in attenuated virulence and motility defects in Burkholderia pseudomallei. BMC Genomics. 2016;17:331. https://doi.org/10.1186/s12864-016-2668-4.

141. Lazar Adler NR, Stevens MP, Dean RE, Saint RJ, Pankhania D, Prior JL, et al. Systematic mutagenesis of genes encoding predicted autotransported proteins of Burkholderia pseudomallei identifies factors mediating virulence in mice, net intracellular replication and a novel protein conferring serum resistance. PLoS One. 2015;10:e121271. https://doi.org/10.1371/journal.pone.

142. Moule MG, Spink N, Willcocks S, Lim J, Guerra-Assunção JA, $\mathrm{Cia} \mathrm{F}$, et al. Characterization of new virulence factors involved in the intracellular growth and survival of Burkholderia pseudomallei. Infect Immun. 2016;84:701-10. https://doi.org/10. 1128/iai.01102-15.

143. Sahl JW, Allender CJ, Colman RE, Califf KJ, Schupp JM, Currie $\mathrm{BJ}$, et al. Genomic characterization of Burkholderia pseudomallei isolates selected for medical countermeasures testing: comparative genomics associated with differential virulence. PLoS One. 2015;10:e0121052. https://doi.org/10.1371/journal.pone.

144. Shea AA, Bernhards RC, Cote CK, Chase CJ, Koehler JW, Klimko CP, et al. Two stable variants of Burkholderia pseudomallei strain MSHR5848 express broadly divergent 
in vitro phenotypes associated with their virulence differences. PLoS One. 2017;12:e0171363. https://doi.org/10.1371/journal. pone.

145. Treerat P, Alwis P, D’Cruze T, Cullinane M, Vadivelu J, Devenish $\mathrm{RJ}$, et al. The Burkholderia pseudomallei proteins BapA and BapC are secreted TTSS3 effectors and BapB levels modulate expression of BopE. PLoS One. 2015;10:e0143916. https://doi. org/10.1371/journal.pone.

146. Vanaporn M, Sarkar-Tyson M, Kovacs-Simon A, Ireland PM, Pumirat P, Korbsrisate S, et al. Trehalase plays a role in macrophage colonization and virulence of Burkholderia pseudomallei in insect and mammalian hosts. Virulence. 2017;8:30-40. https:// doi.org/10.1080/21505594.2016.1199316. In vitro, insect, and mammalian models are all employed to evaluate the role of trehalase in stress response and virulence

147. Welkos SL, Klimko CP, Kern SJ, Bearss JJ, Bozue JA, Bernhards RC, et al. Characterization of Burkholderia pseudomallei strains using a murine intraperitoneal infection model and in vitro macrophage assays. PLoS One. 2015;10:e124667. https://doi.org/10. 1371/journal.pone.

148. Sarkar-Tyson M, Titball RW. Progress toward development of vaccines against melioidosis: a review. Clin Ther. 2010;32: 1437-45. https://doi.org/10.1016/j.clinthera.2010.07.020.

149. Peacock SJ, Limmathurotsakul D, Lubell Y, Koh GC, White LJ, Day NP, et al. Melioidosis vaccines: a systematic review and appraisal of the potential to exploit biodefense vaccines for public health purposes. PLoS Negl Trop Dis. 2012;6:e1488. https://doi. org/10.1371/journal.pntd.0001488.

150.• Limmathurotsakul D, Funnell SG, Torres AG, Morici LA, Brett PJ, Dunachie $\mathrm{S}$ et al. Consensus on the development of vaccines against naturally acquired melioidosis. Emerg Infect Dis. 2015: 21(6) https://doi.org/10.3201/eid2106.141480. This consensus paper includes an anlaysis of research gaps and recommendations for animal modeling and accelerated vaccine development.

151. Muruato LA, Torres AG. Melioidosis: where do we stand in the development of an effective vaccine? Future Microbiol. 2016;11: 477-80. https://doi.org/10.2217/fmb-2015-0018.

152. Silva EB, Dow SW. Development of Burkholderia mallei and pseudomallei vaccines. Front Cell Infect Microbiol. 2013;3:10. https://doi.org/10.3389/fcimb.2013.00010.

153. Choh LC, Ong GH, Vellasamy KM, Kalaiselvam K, Kang WT, Al-Maleki AR, et al. Burkholderia vaccines: are we moving forward? Front Cell Infect Microbiol. 2013;3:5. https://doi.org/10. 3389/fcimb.2013.00005.

154. Patel N, Conejero L, De Reynal M, Easton A, Bancroft GJ, Titball RW. Development of vaccines against Burkholderia pseudomallei. Front Microbiol. 2011;2:198. https://doi.org/10. 3389/fmicb.2011.00198.

155. Dance D. Treatment and prophylaxis of melioidosis. Int $\mathbf{J}$ Antimicrob Agents. 2014;43:310-8. https://doi.org/10.1016/j. ijantimicag.2014.01.005.

156. Estes DM, Dow SW, Schweizer HP, Torres AG. Present and future therapeutic strategies for melioidosis and glanders. Expert Rev Anti-Infect Ther. 2010;8:325-38. https://doi.org/10.1586/eri.10.4.

157. Schweizer HP. When it comes to drug discovery not all Gramnegative bacterial biodefence pathogens are created equal: Burkholderia pseudomallei is different. Microb Biotechnol. 2012;5:581-3. https://doi.org/10.1111/j.1751-7915.2012.00334. $\mathrm{x}$.

158. Sarkar-Tyson M, Atkins HS. Antimicrobials for bacterial bioterrorism agents. Future Microbiol. 2011;6:667-76. https://doi.org/ 10.2217/fmb.11.50.

159. Feterl M, Govan B, Engler C, Norton R, Ketheesan N. Activity of tigecycline in the treatment of acute Burkholderia pseudomallei infection in a murine model. Int J Antimicrob Agents. 2006;28: 460-4. https://doi.org/10.1016/j.ijantimicag.2006.07.022.

160. Harris P, Engler C, Norton R. Comparative in vitro susceptibility of Burkholderia pseudomallei to doripenem, ertapenem, tigecycline and moxifloxacin. Int J Antimicrob Agents. 2011;37:547-9. https://doi.org/10.1016/j.ijantimicag.2011.02.001.

161. Skyberg JA, Rollins MF, Holderness JS, Marlenee NL, Schepetkin IA, Goodyear A, et al. Nasal Acai polysaccharides potentiate innate immunity to protect against pulmonary Francisella tularensis and Burkholderia pseudomallei infections. PLoS Pathog. 2012;8:e1002587. https://doi.org/10.1371/journal. ppat.1002587.

162. Jones SM, Ellis JF, Russell P, Griffin KF, Oyston PC. Passive protection against Burkholderia pseudomallei infection in mice by monoclonal antibodies against capsular polysaccharide, lipopolysaccharide or proteins. J Med Microbiol. 2002;51:1055-62. https://doi.org/10.1099/0022-1317-51-12-1055.

163. Powell K, Ulett G, Hirst R, Norton R. G-CSF immunotherapy for treatment of acute disseminated murine melioidosis. FEMS Microbiol Lett. 2003;224:315-8.

164. Cummings JE, Beaupre AJ, Knudson SE, Liu N, Yu W, Neckles $\mathrm{C}$, et al. Substituted diphenyl ethers as a novel chemotherapeutic platform against Burkholderia pseudomallei. Antimicrob Agents Chemother. 2014;58:1646-51. https://doi.org/10.1128/AAC. 02296-13.

165. Guo P, Zhang J, Tsai S, Li B, Lo SC. Developing peptide mimotopes of capsular polysaccharides and lipopolysaccharides protective antigens of pathogenic Burkholderia bacteria. Monoclon Antib Immunodiagn Immunother. 2016;35:125-34. https://doi.org/10.1089/mab.2015.0073.

166. Zhang S, Feng SH, Li B, Kim HY, Rodriguez J, Tsai S, et al. In vitro and in vivo studies of monoclonal antibodies with prominent bactericidal activity against Burkholderia pseudomallei and Burkholderia mallei. Clin vaccine immunol : CVI. 2011;18:82534. https://doi.org/10.1128/CVI.00533-10.

167. AuCoin DP, Reed DE, Marlenee NL, Bowen RA, Thorkildson P, Judy BM, et al. Polysaccharide specific monoclonal antibodies provide passive protection against intranasal challenge with Burkholderia pseudomallei. PLoS One. 2012;7:e35386. https:// doi.org/10.1371/journal.pone.0035386.

168. Lakshmanan U, Yap A, Fulwood J, Yichun L, Hoon SS, Lim J, et al. Establishment of a novel whole animal HTS technology platform for melioidosis drug discovery. Comb Chem High Throughput Screen. 2014;17:790-803.

169. Ruiz SI, El-Gendy N, Bowen LE, Berkland C, Bailey MM. Formulation and characterization of nanocluster ceftazidime for the treatment of acute pulmonary melioidosis. J Pharm Sci. 2016;105:3399-408. https://doi.org/10.1016/j.xphs.2016.07.029.

170. Asakrah S, Nieves W, Mahdi Z, Agard M, Zea AH, Roy CJ, et al. Post-exposure therapeutic efficacy of COX-2 inhibition against Burkholderia pseudomallei. PLoS Negl Trop Dis. 2013;7:e2212. https://doi.org/10.1371/journal.pntd.0002212.

171. Wilson WJ, Afzali MF, Cummings JE, Legare ME, Tjalkens RB, Allen $\mathrm{CP}$, et al. Immune modulation as an effective adjunct postexposure therapeutic for B. pseudomallei. PLoS Negl Trop Dis. 2016;10:e0005065. https://doi.org/10.1371/journal.pntd. 0005065 .

172. Charoensup J, Sermswan RW, Paeyao A, Promakhejohn S, Punasee S, Chularari C, et al. High HMGB1 level is associated with poor outcome of septicemic melioidosis. Int J Infect Dis. 2014;28:111-6. https://doi.org/10.1016/j.ijid.2014.07.025.

173. Tay TF, Maheran M, Too SL, Hasidah MS, Ismail G, Embi N. Glycogen synthase kinase-3beta inhibition improved survivability of mice infected with Burkholderia pseudomallei. Trop Biomed. 2012;29:551-67. 
174. Laws TR, Clark GC, D'Elia RV. Immune profiling of the progression of a BALB/c mouse aerosol infection by Burkholderia pseudomallei and the therapeutic implications of targeting HMGB1. Int J Infect Dis. 2015;40:1-8. https://doi.org/10.1016/j. ijid.2015.09.003.

175. Sivalingam SP, Sim SH, Jasper LC, Wang D, Liu Y, Ooi EE. Preand post-exposure prophylaxis of experimental Burkholderia pseudomallei infection with doxycycline, amoxicillin/clavulanic acid and co-trimoxazole. J Antimicrob Chemother. 2008;61: 674-8. https://doi.org/10.1093/jac/dkm527.

176. Burtnick MN, Heiss C, Roberts RA, Schweizer HP, Azadi P, Brett PJ. Development of capsular polysaccharide-based glycoconjugates for immunization against melioidosis and glanders. Front Cell Infect Microbiol. 2012;2:108. https://doi.org/10. 3389/fcimb.2012.00108.

177. Scott AE, Ngugi SA, Laws TR, Corser D, Lonsdale CL, D'Elia $\mathrm{RV}$, et al. Protection against experimental melioidosis following immunisation with a lipopolysaccharide-protein conjugate. J Immunol Res. 2014;2014:392170. https://doi.org/10.1155/2014/ 392170.

178. Scott AE, Christ WJ, George AJ, Stokes MG, Lohman GJ, Guo Y, et al. Protection against experimental melioidosis with a synthetic manno-heptopyranose hexasaccharide glycoconjugate. Bioconjug Chem. 2016;27:1435-46. https://doi.org/10.1021/acs. bioconjchem.5b00525.

179. Schully KL, Bell MG, Prouty AM, Gallovic MD, Gautam S, Peine $\mathrm{KJ}$, et al. Evaluation of a biodegradable microparticulate polymer as a carrier for Burkholderia pseudomallei subunit vaccines in a mouse model of melioidosis. Int J Pharm. 2015;495:849-61. https://doi.org/10.1016/j.ijpharm.2015.09.059.

180. Garcia-Quintanilla F, Iwashkiw JA, Price NL, Stratilo C, Feldman MF. Production of a recombinant vaccine candidate against Burkholderia pseudomallei exploiting the bacterial Nglycosylation machinery. Front Microbiol. 2014;5:381. https:// doi.org/10.3389/fmicb.2014.00381.

181. Puangpetch A, Anderson R, Huang YY, Saengsot R, Sermswan $\mathrm{RW}$, Wongratanacheewin S. Comparison of the protective effects of killed Burkholderia pseudomallei and CpG oligodeoxynucleotide against live challenge. Vaccine. 2014;32: 5983-8. https://doi.org/10.1016/j.vaccine.2014.08.035.

182. Nieves W, Asakrah S, Qazi O, Brown KA, Kurtz J, Aucoin DP, et al. A naturally derived outer-membrane vesicle vaccine protects against lethal pulmonary Burkholderia pseudomallei infection. Vaccine. 2011;29:8381-9. https://doi.org/10.1016/j.vaccine.2011. 08.058 .

183. Nieves W, Petersen H, Judy BM, Blumentritt CA, RussellLodrigue K, Roy CJ, et al. A Burkholderia pseudomallei outer membrane vesicle vaccine provides protection against lethal sepsis. Clin Vaccine Immunol. 2014;21:747-54. https://doi.org/10. 1128/CVI.00119-14.

184. Norris MH, Propst KL, Kang Y, Dow SW, Schweizer HP, Hoang TT. The Burkholderia pseudomallei $\Delta$ asd mutant exhibits attenuated intracellular infectivity and imparts protection against acute inhalation melioidosis in mice. Infect Immun. 2011;79:4010-8. https://doi.org/10.1128/IAI.05044-11.

185. Scott AE, Laws TR, D'Elia RV, Stokes MG, Nandi T, Williamson ED, et al. Protection against experimental melioidosis following immunization with live Burkholderia thailandensis expressing a manno-heptose capsule. Clin Vaccine Immunol. 2013;20:1041-7. https://doi.org/10.1128/CVI.00113-13.

186. Moustafa DA, Scarff JM, Garcia PP, Cassidy SK, DiGiandomenico A, Waag DM, et al. Recombinant Salmonella expressing Burkholderia mallei LPS O antigen provides protection in a murine model of melioidosis and glanders. PLoS One. 2015;10:e0132032. https://doi.org/10.1371/journal.pone. 0132032 .
187. Muller CM, Conejero L, Spink N, Wand ME, Bancroft GJ, Titball RW. Role of RelA and SpoT in Burkholderia pseudomallei virulence and immunity. Infect Immun. 2012;80:3247-55. https://doi. org/10.1128/IAI.00178-12.

188. Srilunchang T, Proungvitaya T, Wongratanacheewin S, Strugnell R, Homchampa P. Construction and characterization of an unmarked aroC deletion mutant of Burkholderia pseudomallei strain A2. Southeast Asian J Trop Med Public Health. 2009;40:123-30.

189. Atkins T, Prior RG, Mack K, Russell P, Nelson M, Oyston PC, et al. A mutant of Burkholderia pseudomallei, auxotrophic in the branched chain amino acid biosynthetic pathway, is attenuated and protective in a murine model of melioidosis. Infect Immun. 2002;70:5290-4.

190. Amemiya K, Dankmeyer JL, Fetterer DP, Worsham PL, Welkos SL, Cote CK. Comparison of the early host immune response to two widely diverse virulent strains of Burkholderia pseudomallei that cause acute or chronic infections in BALB/c mice. Microb Pathog. 2015;86:53-63. https://doi.org/10.1016/j.micpath.2015. 07.004 .

191. Wiersinga WJ, Wieland CW, Dessing MC, Chantratita N, Cheng AC, Limmathurotsakul D, et al. Toll-like receptor 2 impairs host defense in gram-negative sepsis caused by Burkholderia pseudomallei (Melioidosis). PLoS Med. 2007;4:e248. https://doi. org/10.1371/journal.pmed.0040248.

192. West TE, Ernst RK, Jansson-Hutson MJ, Skerrett SJ. Activation of Toll-like receptors by Burkholderia pseudomallei. BMC Immunol. 2008;9:46. https://doi.org/10.1186/1471-2172-9-46.

193. Chantratita N, Tandhavanant S, Myers ND, Seal S, Arayawichanont A, Kliangsa-Ad A, et al. Survey of innate immune responses to Burkholderia pseudomallei in human blood identifies a central role for lipopolysaccharide. PLoS One. 2013;8:e81617. https://doi.org/10.1371/journal.pone.0081617.

194. Korneev KV, Arbatsky NP, Molinaro A, Palmigiano A, Shaikhutdinova RZ, Shneider MM, et al. Structural relationship of the lipid a acyl groups to activation of murine toll-like receptor 4 by lipopolysaccharides from pathogenic strains of Burkholderia mallei, Acinetobacter baumannii, and Pseudomonas aeruginosa. Front Immunol. 2015;6:595. https://doi.org/10.3389/fimmu. 2015.00595.

195. Weehuizen TA, Prior JL, van der Vaart TW, Ngugi SA, Nepogodiev SA, Field RA, et al. Differential toll-like receptorSignalling of Burkholderia pseudomallei lipopolysaccharide in murine and human models. PLoS One. 2015;10:e145397. https://doi.org/10.1371/journal.pone.0145397.

196. Norris MH, Schweizer HP, Tuanyok A. Structural diversity of Burkholderia pseudomallei lipopolysaccharides affects innate immune signaling. PLoS Negl Trop Dis. 2017;11:e0005571. https:// doi.org/10.1371/journal.pntd.0005571.

197. Hii CS, Sun GW, Goh JW, Lu J, Stevens MP, Gan YH. Interleukin-8 induction by Burkholderia pseudomallei can occur without Toll-like receptor signaling but requires a functional type III secretion system. J Infect Dis. 2008;197:1537-47. https://doi. org/10.1086/587905.

198. Brett PJ, Burtnick MN, Snyder DS, Shannon JG, Azadi P, Gherardini FC. Burkholderia mallei expresses a unique lipopolysaccharide mixture that is a potent activator of human Toll-like receptor 4 complexes. Mol Microbiol. 2007;63:379-90. https:// doi.org/10.1111/j.1365-2958.2006.05519.x.

199. Zhao Y, Yang J, Shi J, Gong YN, Lu Q, Xu H, et al. The NLRC4 inflammasome receptors for bacterial flagellin and type III secretion apparatus. Nature. 2011;477:596-600. https://doi.org/10. 1038/nature10510.

200. Zhang L, Chen S, Ruan J, Wu J, Tong AB, Yin Q, et al. Cryo-EM structure of the activated NAIP2-NLRC4 inflammasome reveals nucleated polymerization. Science. 2015;350:404-9. https://doi. org/10.1126/science.aac5789. 
201. West TE, Myers ND, Chantratita N, Chierakul W, Limmathurotsakul D, Wuthiekanun V, et al. NLRC4 and TLR5 each contribute to host defense in respiratory melioidosis. PLoS Negl Trop Dis. 2014;8:e3178. https://doi.org/10.1371/journal. pntd.0003178.

202. Ceballos-Olvera I, Sahoo M, Miller MA, Del Barrio L, Re F. Inflammasome-dependent pyroptosis and IL-18 protect against Burkholderia pseudomallei lung infection while IL-1beta is deleterious. PLoS Pathog. 2011;7:e1002452. https://doi.org/10.1371/ journal.ppat.1002452.

203. Easton A, Haque A, Chu K, Lukaszewski R, Bancroft GJ. A critical role for neutrophils in resistance to experimental infection with Burkholderia pseudomallei. J Infect Dis. 2007;195:99-107. https://doi.org/10.1086/509810.

204. Chanchamroen S, Kewcharoenwong C, Susaengrat W, Ato M, Lertmemongkolchai G. Human polymorphonuclear neutrophil responses to Burkholderia pseudomallei in healthy and diabetic subjects. Infect Immun. 2009;77:456-63. https://doi.org/10.1128/iai. 00503-08.

205. Propst KL, Mima T, Choi KH, Dow SW, Schweizer HP. A Burkholderia pseudomallei deltapurM mutant is avirulent in immunocompetent and immunodeficient animals: candidate strain for exclusion from select-agent lists. Infect Immun. 2010;78: 3136-43. https://doi.org/10.1128/IAI.01313-09.

206. Gutierrez MG, Warawa JM. Attenuation of a select agentexcluded Burkholderia pseudomallei capsule mutant in hamsters. Acta Trop. 2016;157:68-72. https://doi.org/10.1016/j.actatropica. 2015.12.006.

207. Atkins T, Prior R, Mack K, Russell P, Nelson M, Prior J, et al. Characterisation of an acapsular mutant of Burkholderia pseudomallei identified by signature tagged mutagenesis. J Med Microbiol. 2002;51:539-47. https://doi.org/10.1099/0022-131751-7-539.

208. Warawa JM, Long D, Rosenke R, Gardner D, Gherardini FC. Role for the Burkholderia pseudomallei capsular polysaccharide encoded by the $w c b$ operon in acute disseminated melioidosis. Infect Immun. 2009;77:5252-61. https://doi.org/10.1128/IAI. 00824-09.
209. Barnes KB, Steward J, Thwaite JE, Lever MS, Davies CH, Armstrong SJ, et al. Trimethoprim/sulfamethoxazole (cotrimoxazole) prophylaxis is effective against acute murine inhalational melioidosis and glanders. Int $\mathrm{J}$ Antimicrob Agents. 2013;41:552-7. https://doi.org/10.1016/j.ijantimicag.2013.02. 007.

210. Gelhaus HC, Anderson MS, Fisher DA, Flavin MT, Xu ZQ, Sanford DC. Efficacy of post exposure administration of doxycycline in a murine model of inhalational melioidosis. Sci Rep. 2013;3:1146. https://doi.org/10.1038/srep01146.

211. Ulett GC, Hirst R, Bowden B, Powell K, Norton R. A comparison of antibiotic regimens in the treatment of acute melioidosis in a mouse model. J Antimicrob Chemother. 2003;51:77-81.

212. Haussler S, Rohde M, Steinmetz I. Highly resistant Burkholderia pseudomallei small colony variants isolated in vitro and in experimental melioidosis. Med Microbiol Immunol. 1999;188:91-7.

213. Keren I, Kaldalu N, Spoering A, Wang Y, Lewis K. Persister cells and tolerance to antimicrobials. FEMS Microbiol Lett. 2004;230: $13-8$.

214. Nierman WC, Yu Y, Losada L. The in vitro antibiotic tolerant persister population in Burkholderia pseudomallei is altered by environmental factors. Front Microbiol. 2015;6:1338. https://doi. org/10.3389/fmicb.2015.01338.

215. Cummings JE, Slayden RA. Transient in vivo resistance mechanisms of Burkholderia pseudomallei to ceftazidime and molecular markers for monitoring treatment response. PLoS Negl Trop Dis. 2017;11:e005209. https://doi.org/10.1371/journal.pntd. 0005209. In this recent article, the authors characterized transcriptional responses of $B$. pseudomallei in mice (specific to ceftazidime exposure) to identify markers of treatment efficacy

216. Tuanyok A, Tom M, Dunbar J, Woods DE. Genome-wide expression analysis of Burkholderia pseudomallei infection in a hamster model of acute melioidosis. Infect Immun. 2006;74:5465-76. https://doi.org/10.1128/IAI.00737-06.

217. Moule M, Spink N, Willcocks S, Lim J, Guerra-Assuncao J, Wren BW. Characterization of new virulence factors involved in the intracellular growth and survival of Burkholderia pseudomallei. Infect Immun. 2016;84:701-10. 